JSS $2 / 88$

The links Between Competences Acquired through Interdisciplinary

Studies and the

Needs of the Labour Market

Submitted

01/2015

Accepted for publication 02/2015
The Links Between Competences Acquired through Interdisciplinary Studies and the Needs of the Labour Market Tarpdalykinių studijų metu igyjamų kompetencijų ir darbo rinkos poreikių sąsajos

\section{Nijolè Putrienè}

Kaunas University of Technology

K. Donelaicio str. 73, Kaunas

$\Gamma$ Crossef http://dx.doi.org/10.5755/j01.ss.88.2.12741

The complexity of competences required by the labour market has made it necessary to change the traditional patterns of education. An assumption can be made that students could develop competences that are required by the market through interdisciplinary studies and team-teaching in that. For this reason, the question asked in this paper is what competences necessary for the labour market are developed through interdisciplinary studies and team-teaching.

The paper uses the method of literature review.

It has been found that interdisciplinary studies that involve team-teaching enable students to acquire such skills as applying multi-perspective approach to problem-solving, accepting different points of view and thinking 'outside the box'. Students learn to build new and expand existing knowledge, accept and provide constructive feedback as well as express their own opinion. These competences are highly important in the contemporary working world; therefore, it can be stated that the implementation of such studies opens the way to a successful career of the graduates.

KEYWORDS: interdisciplinary studies; team-teaching; competences; labour market. 
For a long time, higher education has been an engine for social change. In the contemporary world, tendencies have been observed suggesting that, quite often, social change has an influence on higher education and, thus, forces it to alter.

The trends of increase in the number of higher education institutions and prevalence of global knowledge economy have influenced higher education by turning it into a means for generating economic capital (Barnett, 1996), whereas universities have chosen to focus on the development of competences that are necessary for the labour market (Barnett, 1996; Bulajeva and Duobliene, 2009; Davies and Devlin, 2010; Zelvys, 2005, 2007).

Traditional university study programmes used to rely on the approach that universities have to create fundamental knowledge to be further introduced to the general public. Such a pattern of building knowledge dealt with questions of one particular discipline and was not related with the needs of the social environment (Light, Cox and Calkins, 2009). However, single-subject studies can no longer satisfy the needs of the modern world (Taylor, 2011); thus, as a consequence, higher education institutions are increasingly developing and providing study programmes combining several disciplines.

Interdisciplinary links in higher education are becoming more and more common. Along with other tendencies affecting higher education (such as increase in the number of non-traditional students, boost in popularity of asynchronous learning etc.), interdisciplinary studies has also made team-teaching an increasingly widespread way of teaching at universities.

However, the question is whether such changes in higher education may indeed allow for the conclusion that their implementation in the study process will affect the competences acquired by the students. What influence do interdisciplinary studies and team-teaching have on the learning process? These and other questions become especially relevant when searching for links between the modern labour market and opportunities for graduates to become its successful players. Due to these reasons, this paper focuses on the question: what competences relevant for the labour market are developed through interdisciplinary studies and team-teaching?

The paper uses the method of literature rewiev.

The paper consists of three parts. The first part discusses the concepts of interdisciplinarity and interdisciplinary study programmes, while the second part analyses the definition of team-teaching. The final part reveals the influence made by interdisciplinary studies and team-teaching on the competences acquired by students.

According to Klein (1999), the period between 1875 and 1910 gave rise to 'disciplining of the curriculum'. Twenty or twenty-five disciplines replaced a single successive sequence of studies and each of them had its own organisational departments, provided its own degrees and developed its own study programmes. The intensive specialisation in science manifested itself in scientific research, too. In the middle of the $20^{\text {th }}$ century, in response to these changes, reverse tendencies became more prominent leading to the rise of cooperation among representatives of different disciplines in interdisciplinary research, which prompted to search for ways of defining such types of activities (Kanisauskas, 2011; Klein, 2000, 2010; Lattuca, 2001; Max-Neef, 2005).

The term interdisciplinarity covers a wide scope of integration and interaction of disciplines and cooperation among scientists. The typology published in 1972 by OECD, which most likely aimed at defining the links among various interdisciplinary activities, distinguished three trends of interdisciplinarity, namely, multidisciplinarity, interdisciplinarity and transdis-

\section{The definition of inter- disciplinarity and inter- disciplinary study programmes}


ciplinarity (Klein, 2010) to show the differences in the degree of integration and interaction of disciplines: from the lowest in the case of multidisciplinarity to the highest degree in the case of transdisciplinarity.

So far, research papers have revealed the limitations of a clearer definition of the above-mentioned terms (as well as other related terms) and confusion among the terms related to a dual approach to interdisciplinarity (Choi and Pak, 2006; Knight, Lattuca, Kimball and Reason, 2013). Nevertheless, having summarised a number of publications in the field (Choi and Pak, 2006; Hyun, 2011; Klein, 2010; Knight et al., 2013; McCulloch, 2012; Wright, Byers, Dyball, Hazelton and Radich, 2011) one may note that interdisciplinarity (as a trend located between multidisciplinarity and transdisciplinarity) is integration and interaction of equal disciplines created as a result of active cooperation of scientists and/or teachers within scientific research or studies and aims to solve complex problems or analysing complex phenomena by taking a more holistic perception of these problems or phenomena.

Meanwhile, Newell $(2007,2011)$ defines interdisciplinary studies in higher education as a process that involves academic disciplines and requires their integration. Such studies are a two-part process: they evaluate the disciplinary approach in a critical way and combine insights of different disciplines by creating a more profound understanding of an existing phenomenon. Jones (2010) shares a similar view by stating that interdisciplinary studies occur when students are enabled to approach the problem from different perspectives, while the essential aim of the studies is to create a synthesis of discipline-based knowledge. In such a case, according to Rives-East and Lima (2013), in an interdisciplinary study programme, different disciplines view the same problem from multiple perspectives, and these points of view are simultaneously presented to the students, whereas the boundaries between the disciplines are vague. However, Badley (2009) adds that such study programmes should encourage students to perceive links among the disciplines. Furthermore, Newell (2007) appends that interdisciplinary programmes integrate, but not contrast, whatever they transfer from the disciplines and/or deliberately control this process. Bajada and Trayler (2013) approach this in a simpler way: the content of interdisciplinary study programmes has to be designed on the basis of discipline-based knowledge; however, separate problems analysed within a study programme should not be viewed within the boundaries of a single discipline, but each problem should be simultaneously discussed from the perspective of different disciplines.

Consequently, having summarised views of the above-mentioned scientists and other researchers, an interdisciplinary study programme can be defined as a study programme comprising modules that have been designed on the basis of two or more disciplines and implemented - which is an important factor - through active cooperation among teachers (and, presumably, students), while the learning goal is to create a perception of the analysed phenomena based on the integration and synthesis of knowledge from certain disciplines.

\section{The definition of team- teaching}

When writing about interdisciplinary studies in higher education, scientists (e.g., Badley, 2009; Bajada and Trayler, 2013; Newell, 1992; Rives-East and Lima, 2013; Wright et al., 2011) usually emphasise the importance of team-teaching for the successful implementation of these studies. Thus, what is team-teaching? It should be specified that this paper does not analyse the phenomenon of teamwork. Various aspects of teamwork, team formation and team efficiency have been analysed in a wide range of works both by Lithuanian and foreign researchers (e.g., Chen, Kirkman, Kanfer, Allen and Rosen, 2007; Kirkman, Rosen, Tesluk and Gibson, 2004; Kirkman and Rosen, 2000; M. A. Marks et al., 2001; Simanskiene and Seilius, 2009; West, 2011; Zydziunaite, 2003); however, they are not separately discussed in this paper. 
Scientists slightly differ in their explanation and definition of team-teaching. As Gurgur and Uzuner (2011) have noticed, team-teaching is one of branches of co-teaching. The researchers indicate that co-teaching takes place when two educators teach two separate subgroups of learners; however, they plan the learning process together and pursue common learning goals. Meanwhile, team-teaching occurs when two trainers or teachers lead a discussions in rotation or change their roles during the classes. A similar approach has been taken by Quinn and Kanter (1984; cited in Laughlin et al., 2011) who claim that team-teaching is a teamwork of two professional teachers together delivering lectures to the audience.

These definitions emphasise the key essence of team-teaching, namely, that it involves two teachers working simultaneously with the students. Nevertheless, at the same time we are faced with certain questions; for instance, does team-teaching involve just two teachers? Or, is team-teaching limited solely to delivering lectures? After all, learning in the contemporary society is a phenomenon too broad to be confined just to this single teaching activity.

Wenger and Hornyak (1999) expand the definition by stating that team-teaching involves two or more teachers at a specified level sharing the responsibility for a group of students. In the meantime, Buckeley (1999) suggests that team-teaching embraces a group of teachers or trainers working in a purposeful, consistent and cooperative manner in order to assist a group of students in learning.

Although the latter definitions are no longer confined to just two teachers, such an approach to team-teaching raises further questions. What does it mean to share responsibility for a group of students? What kind of responsibility is to be shared? What types of activities are to be commonly delivered by the group of teachers to assist their students in learning?

Kreber (2000) describes the work of a teacher as three-fold: it comprises teaching, conducting and disseminating research, and providing services to the employing institution and the general public. Meanwhile, according to Postareff \& Lindblom-Ylanne (2008), the teaching process consists of three key parts: planning of teaching, teaching in practice, and assessment of the student performance. Taking this remark into consideration, it can be stated that the most precise definition of team-teaching has been suggested by Day \& Hurrell (2012) and Laughlin et al. (2011). These scientists indicate that team-teaching occurs when a group of two or more teachers work together to plan, conduct and assess the learning process of the same group of learners.

As it has been mentioned earlier, team-teaching is often an integral part of implementing interdisciplinary study programmes. However, what are the specifics of such programmes and what are the peculiarities of team-teaching within these programmes? What competences do they help students to develop?

The very definition of interdisciplinarity and interdisciplinary studies allows for insight into certain aspects that should be relevant when talking about competences acquired by students. These include a skill to integrate and synthesise knowledge, a skill to approach a phenomenon from different perspectives, and communication skills. The above-mentioned skills are as well important for working environment; however, it is obvious that the skills, abilities and knowledge the students acquire within interdisciplinary studies go far beyond these three skills.

Jacobs (1989) (speaking, in fact, about general education programmes) notices that an interdisciplinary programme has to develop both competences that are typical of a certain discipline and interdisciplinary competences. It is evident that every single discipline that is

\section{Competences acquired within inter- disciplinary studies and team-teaching}


integrated within an interdisciplinary study programme sets its own specific goals for developing student skills and knowledge. However, what are the specifics of interdisciplinary competences? What knowledge, skills and abilities do students have to acquire to let us claim that they have acquired interdisciplinary competences?

It could be noticed that researchers do not usually emphasise any particular knowledge that a student should acquire within interdisciplinary studies. The very definition of the term interdisciplinarity shows that the knowledge acquired within interdisciplinary studies depends on the disciplinary knowledge but broadens it (Barrett, 2012; Holley, 2013; McCulloch, 2012) or, as Hyun (2011) has stated, goes beyond the existing boundaries of the disciplinary knowledge.

Nevertheless, when speaking about knowledge acquisition, we are faced with one specific problem which becomes relevant in the case of interdisciplinary education. Scientists (e.g., Badley, 2009; Davies and Devlin, 2010) draw attention to the problem of the compatibility between the depth and breadth of knowledge which is especially important in higher education. According to Klein (1999), the depth ensures the acquisition of relevant disciplinary, professional and interdisciplinary knowledge, and information necessary to achieve the set goals. The breadth enables to look at a separate aspect from different perspectives. The synthesis of the depth and breadth of knowledge ensures the development of holistic comprehension. Students should acquire sufficiently deep disciplinary knowledge to be able to discover links between knowledge from different disciplines (Badley, 2009); for the synthesis of disciplinary knowledge to occur (Ivanitskaya, Clark, Montgomery and Primeau, 2002; Jones, 2010; Newell, 2007, 2011); to create new knowledge by means of this synthesis (Choi and Pak, 2006; Knight, 2011; Newell, 2001) or develop the knowledge already applied in practice (Weinberg and Harding, 2004).

While scientists do not frequently focus on the subject of knowledge as an objective of interdisciplinary study programmes, they instead place a lot of emphasis on skills and abilities to be acquired within these programmes.

Newell (1994) claims that interdisciplinary studies have to develop cognitive abilities of students, and Ivanitskaya et al. (2002), Lattuca, Voight and Fath (2004), Spelt, Biemans, Tobi, Luning and Mulder (2009) add that in this case it is the higher-order cognitive abilities that should be mostly considered. After all, cognitive abilities may vary to a large extent. Therefore, what kind of cognitive abilities should be developed in the case of interdisciplinary studies?

Craddock, O'Halloran, McPherson, Hean and Hammick (2013) claim that interdisciplinary studies have to be focused on the development of systematic, methodical and analytical thinking skills, as it is precisely these skills that help to perceive links between different activities. Newell $(1992,2001)$, Ivanitskaya et al. (2002), Lattuca et al. (2004) indicate the necessity for developing critical thinking skills in interdisciplinary studies. Newell (1992) adds that studies supported by a single discipline develop 'a weak sense of critical thinking' during the formation of logical thinking skills. Meanwhile, interdisciplinary studies develop 'a strong sense of critical thinking'. During such studies, students analyse different views expressed by various disciplines. They learn to approach the same phenomenon from different perspectives. Thus, students are encouraged to recognise potential limitations and irrationality of their own views and approaches. Yet, the scientist claims that the development of both 'strong' and 'weak' critical thinking is important and pursued in higher education; therefore, interdisciplinary studies should develop this 'dual' combination of critical thinking skills.

Davies and Devlin (2010) remind that interdisciplinarity requires thinking beyond the set boundaries. Spelt et al. (2009) support this by claiming that interdisciplinary studies have to 
develop boundary-crossing skills. By developing such skills students have primarily to learn to critically analyse the available knowledge (Spelt et al., 2009), i.e. to continuously face the challenge, learn to ask 'why?' and not to accept an expert's evaluation as the absolute truth (Newell, 1994). In addition, students should learn to approach a phenomenon from several perspectives (Lattuca et al., 2004), establish links among theories, approaches, methods, concepts and paradigms, i.e., be able to interpret (Ivanitskaya et al., 2002). Later on, students should develop an ability to synthesise and integrate knowledge from different disciplines, make conclusions and take effective solutions on the basis of ambiguous information (Knight et al., 2013; Spelt et al., 2009).

Woods (2007) emphasises yet another important goal of interdisciplinary studies. The researcher claims that the essential prerequisite for implementation of such studies (and, afterwards, when working in the interdisciplinary environment) is an ability to understand others and be understood by others, i.e., there is a necessity for interdisciplinary communicative competence. Therefore, this competence should be as well developed within interdisciplinary studies. According to Woods (2007), this competence comprises two components which in turn compound other minor skills, such as an ability to communicate across academic knowledge domains and skills of effective communication with representatives of different academic cultures.

The particular relevance of the above-mentioned skills for interdisciplinarity and interdisciplinary studies has as well been emphasised by other scientists (however, they do not unite these skills into a single whole). For instance, Newell (1994) states that interdisciplinarity in studies develops a broad view and, at the same time, an ability to accept a different view, an enhanced ability to listen thoroughly to a different opinion, and empathy for a diversity in disciplinary, political and religious beliefs. The scientist adds that interdisciplinary education teaches respect for others who share different views and opinions. In the meantime, Hall and Weaver (2001) emphasise the disappearance of boundaries between different cultures and the importance of collaborative, communicative and conflict-solving skills in interdisciplinary education.

Consequently, interdisciplinary studies enable students to create new knowledge or develop the available knowledge by integrating various information, approach a situation from different perspectives, think beyond the set boundaries, and make decisions on the basis of ambiguous information. Moreover, students develop a skill of communicating with others who share different opinions and accept such opinions. It is obvious that most of these competences are especially relevant in the modern working world.

Nevertheless, it may be claimed that the competences acquired in the interdisciplinary studies cannot be limited to the above-mentioned competences. As mentioned above, team-teaching is a common element of interdisciplinary studies. The phenomenon of team-teaching also has an influence on student competences.

The analysis of different typologies of team-teaching (e.g., discussed in the works of Dionne, 2011; Laughlin et al., 2011; Wenger and Hornyak, 1999) allows for the conclusion that the key aspect defining a certain type of team-teaching is sharing responsibility among the teachers and the extent of mutual cooperation. Wenger and Hornyak (1999) show that the higher the extent of cooperation among the teachers, the higher the level of learning according to Bloom's taxonomy (1971) that can be achieved by the students. The researchers claim that if teachers teach in rotation, without an interactive discussion, the learning remains on the level of knowledge and comprehension. However, it should be emphasised that this type of team-teaching is not acceptable within interdisciplinary studies. Interdisciplinary education requires a considerably higher level of mutual cooperation among teachers. 
The second type of team-teaching distinguished by Wenger and Hornyak (1999) describes a situation where teachers in rotation add to each other's presentation or provide contrasting views. In this case, students learn to apply and analyse the acquired knowledge. During team-teaching sessions, where the interaction among the teachers reaches the highest level and teachers are naturally, without prior preparation, engaged in a discussion or debates and provide contrasting viewpoints to students, the latter acquire the skills of knowledge synthesis and value-based assessment. It could be claimed that it is this third type of teamteaching distinguished by Wenger and Hornyak (1999) that should be recognised as a characteristic feature of interdisciplinary studies.

Obviously, it should be recognised that team-teaching may not always be an advantage for students. Caviglia-Harris and Hatley (2004), Laughlin et al. (2011) indicate that students may feel uncomfortable and confused by being taught by more than a single teacher. However, planning the teaching process thoroughly and sharing responsibilities among the teachers will make it possible to avoid such negative aspects of team-teaching. Thus, it is not surprising that scientists usually tend to emphasise the positive effect of team-teaching on the student learning.

As suggested by Little and Hoel (2011), team-teaching enables a bigger number of students to actively participate in the class. In the cases when the class is run by several teachers, the interaction among teachers and students increases. This may make an essential contribution to the achievement of the learning outcomes. Laughlin et al. (2011) add that different teaching styles may help students develop an ability to learn in different ways, which can enhance the comprehension of the information provided and increase the level of retaining this information.

Another aspect that is relevant for team-teaching, according to Laughlin et al. (2011), is that during team-teaching sessions students are exposed to different viewpoints expressed by the teachers. This develops critical thinking skills and encourages students to appreciate a variety of opinions shared by peers, which leads towards accepting the importance of diversity and multiplicity. Furthermore, as Shibley Jr. (2006) indicates, a discussion among teachers in the classroom enables students to realise that constructive criticism is not directed against a certain person but aims at better understanding of the concept under discussion. This inspires students to express their own point of view.

Scherpereel and Bowers (2006) highlight another important advantage of team-teaching: students are provided with an opportunity to observe modelled situations of team-work. Thus, students can learn about different situations arising in the professional environment. A team of teachers manage time, solve conflicts and professional disagreements, and in this way students learn how to cooperate. The researchers even make an assumption that students are better prepared to act in a modern horizontal organisational structure when they are exposed to a teamwork modelling during team-teaching sessions.

Consequently, one may claim that team-teaching in interdisciplinary studies enables a more active and engaged participation of students in the learning process. This type of teaching helps students to learn in different ways, synthesise knowledge and evaluate the provided information according to value-based attitudes; it contributes to the comprehension level and increases the level of retaining the information. By observing the teachers during teamteaching sessions students learn to appreciate diverse opinions, be able to accept and provide constructive criticism, express their own point of view. In addition to this, a well-organised team-teaching may introduce students to the specifics of teamwork. 
The modern business environment expresses a demand for employees possessing multiple competences. Unfortunately, it is frequently stated that higher education graduates do not acquire such competences during the studies. Interdisciplinary studies and team-teaching as a part of such studies came into existence in order to meet the needs of the business world; thus, it could be claimed that this type of studies should provide students with the required competences.

Interdisciplinary study programmes as well combine interdisciplinary modules developed on the basis of separate disciplines. Interdisciplinarity in studies requires both interaction and integration of disciplines of equal value and engaging cooperation among teachers representing different disciplines and students so that the latter would learn to analyse complex phenomena.

Team-teaching shows a common work of two or more teachers working simultaneously with the same students. In interdisciplinary studies, this type of teaching significantly enhances competences developed by the students and contributes to the development of several additional abilities.

In interdisciplinary studies, students acquire skills to approach the existing problems from various perspectives, accept different viewpoints, think 'in a broader way' by going beyond 'the set boundaries', which enables the learners to create new knowledge and develop the existing knowledge, i.e., students learn to create and welcome innovation. Team-teaching has a further influence on the competences of students: they learn to learn in different ways, accept and provide constructive criticism, express their own opinion. These skills are especially important in the modern working environment where there is a continuous increase in situations demanding teamwork. Both team working skills and abilities to create and transfer innovation have a particular relevance for modern organisations; therefore, one may claim that interdisciplinary studies comprising team-teaching elements create prerequisites for a successful career of higher education graduates.

Badley, K. (2009). Resisting curriculum integration: do good fences make good neighbors? Issues in Integrative Studies, 27, 113-137.

Bajada, C., \& Trayler, R. (2013). Interdisciplinary business education: curriculum through collaboration. Education + Training, 55(4/5), 385-402.

Barnett, R. (1996). The Limits of Competence. Knowledge, Higher Education and Society. Buckingham: SRHE \& Open University Press.

Barrett, B. D. (2012). Is interdisciplinarity old news? A disciplined consideration of interdisciplinarity. British Journal of Sociology of Education, 33(1), 97-114. http://dx.doi.org/10.1080/01425692.201 2.632868

Brint, S. G., Turk-Bicakci, L., Proctor, K., \& Murphy, S. P. (2009). Expanding the Social Frame of Knowledge: Interdisciplinary, Degree-Granting Fields in American Colleges and Universities,

\section{Conclusions}


Choi, B. C. K., \& Pak, A. W. P. (2006). Multidisciplinarity, interdisciplinarity and transdisciplinarity in health research, services, education and policy: 1. Definitions, objectives, and evidence of effectiveness. Clinical and Investigative Medicine. Medecine Clinique et Experimentale, 29(6), 351-364.

Craddock, D., O'Halloran, C., McPherson, K., Hean, S., \& Hammick, M. (2013). A top-down approach impedes the use of theory? Interprofessional educational leaders'approaches to curriculum development and the use of learning theory. Journal of Interprofessional Care, (27), 65-72. http://dx.doi.org/10.3109/13561820.2012.736888

Day, L., \& Hurrell, D. (2012). A teaching team: More than the sum of its parts. In Creating an inclusive learning environment: Engagement, equity, and retention. Proceedings of the 21 st Annual Teaching Learning Forum.

Davies, M., \& Devlin, M. (2010). Interdisciplinary higher education. In Interdisciplinary Higher Education: Perspectives and Practicalities (pp. 3-28). Emerald Group Publishing Limited.

Gurgur, H., \& Uzuner, Y. (2011). Examining the implementation of two co-teaching models: team teaching and station teaching. International Journal of Inclusive Education, 15(6), 589-610. http:// dx.doi.org/10.1080/13603110903265032

Hall, P., \& Weaver, L. (2001). Interdisciplinary education and teamwork: a long and winding road. Medical Education, 35, 867-875. http:// dx.doi.org/10.1046/j.1365-2923.2001.00919.x

Hyun, E. (2011). Transdisciplinary higher education curriculum: a complicated cultural artifact. Research in Higher Education Journal, 11 (1), 1-19.

Holley, K. A. (2013). Doctoral education and the development of an interdisciplinary identity. Innovations in Education and Teching International, 1-11. http://dx.doi.org/10.1080/14703297.2013.8 47796

Ivanitskaya, L., Clark, D., Montgomery, G., \& Primeau, R. (2002). Interdisciplinary Learning: Process and Outcomes. Innovative Higher Education, 27(2), 95-111. http://dx.doi. org/10.1023/A:1021105309984

Jacobs, H. H. (Ed.). (1989). Interdisciplinary Curriculum. Design and Implementation. ASCD.

Kanišauskas, S. (2011). Transdisciplininis projektas: proveržii i mokslų ir praktikos sintezę? Problemos, 80, 107-115.
Kirkman, B. L., \& Rosen, B. (2000). Powering Up Teams. Organizational Dynamics, Winter, 48-66. http://dx.doi.org/10.1016/S00902616(00)88449-1

Kirkman, B. L., Rosen, B., Tesluk, P. E., \& Gibson, C. B. (2004). The Impact of Team Empowerment on Virtual Team Performance: The Moderating Role of Face-to-Face Interaction. Academy of Management Journal. http://dx.doi. org/10.2307/20159571

Klein, J. T. (1999). Mapping Interdisciplinary Studies. Association of American Colleges and Universities.

Klein, J. T. (2000). A conceptual vocabulary of interdisciplinary science. In P. Weingart \& N. Stehr (Eds.), Practicing interdisciplinary (pp. 3-24). Toronto: university of Toronto press.

Klein, J. T. (2010). A taxonomy of interdisciplinarity. In R. Frodeman, J. T. Klein, C. Mitcham, \& J. B. Holbrook (Eds.), The Oxford Handbook of Interdisciplinarity (pp. 15-30). Oxford: Oxford university press.

Knight, D. B. (2011). Educating broad thinkers: A quantitative analysis of curricular and pedagogical techniques used to promote interdisciplinary skills. In Proceedings of the 118th Annual Conference of the American Society for Engineering Education, Vancouver, BC, Canada.

Knight, D. B., Lattuca, L. R., Kimball, E. W., \& Reason, R. D. (2013). Understanding Interdisciplinarity: Curricular and Organizational Features of Undergraduate Interdisciplinary Programs. Innovative Higher Education, 38, 143-158. http:// dx.doi.org/10.1007/s10755-012-9232-1

Kreber, C. (2000). Integrating Teaching with Other Aspects of Professioral Work: A Comparison of Experienced and Inexperienced Faculty's Role Conceptualizations. The Canadian Journal of Higher Educarion, XXX(3), 79-112.

Larson, E. L., Landers, T. F., \& Begg, M. D. (2011). Building Interdisciplinary Research Models: A Didactic Course to Prepare Interdisciplinary Scholars and Faculty. Clinical and Translational Science, 4(1), 38-41. http://dx.doi.org/10.1111/ j.1752-8062.2010.00258.x

Lattuca, L. R. (2001). Creating interdisciplinarity. Interdisciplinary research and teaching among college and university faculty. Vanderbilt university press. 
Lattuca, L. R., Voight, L. J., \& Fath, K. Q. (2004). Does Interdisciplinarity Promote Learning? Theoretical Support and Researchable Questions. The Review of Higher Education, 28(1), 23-48. http:// dx.doi.org/10.1353/rhe.2004.0028

Laughlin, K., Nelson, P., \& Donaldson, S. (2011). Successfully Applying Team Teaching with Adult Learners. Journal of Adult Education, 40(1), 1118.

Light, G., Cox, R., \& Calkins, S. (2009). Learning and Teaching in Higher Education - the Reflective Professional. Second Edition. London: Sage Publications.

Little, A., \& Hoel, A. (2011). Interdisciplinary Team Teaching: An Effective Method to Transform Student Attitudes. The Journal of Effective Teaching, 11(1), 36-44.

MacKinnon, P. J., Hine, D., \& Barnard, R. T. (2013). Interdisciplinary science research and education. Higher Education Research and Development, 32(3), 407-419. http://dx.doi.org/10.1080/07294 360.2012 .686482

Marks, M. A., Mathieu, J. E., \& Zaccaro, S. J. (2001). A temporally based framework and taxonomy of team processes. Academy of Management Review, 28(3), 356-376.

Max-Neef, M. A. (2005). Foundations of transdisciplinarity. Ecological Economics, 53, 5-16. http://dx.doi.org/10.1016/j.ecolecon.2005.01.014

McCulloch, G. (2012). Introduction: disciplinarity, interdisciplinarity and educational studies - past, present and future. British Journal of Educational Studies, 60(4), 295-300. http://dx.doi.org/10.1080 /00071005.2012.744185

Newell, W. H. (1992). Academic Disciplines and Undergraduate Interdisciplinary Education: lesson from the School of Interdisciplinary Studies at Miami University, Ohio. European Journal of Education, 27(3), 211-221. http://dx.doi. org/10.2307/1503450

Newell, W. H. (1994). Designing Interdisciplinary Courses. New Directions for Teaching and Learning, 58, 35-51. http://dx.doi.org/10.1002/ tl.37219945804

Newell, W. H. (2001). A Theory of Interdisciplinary Studies. Issues in Integrative Studies, 19, 1-25.

Newell, W. H. (2007). Six arguments for agreeing on a definition of interdisciplinary studies. Asso- ciation for Integrative Studies Newsletter, 29(4), 1-4. Retrieved from http://www.units.muohio. edu/aisorg/pubs/news/dec07.pdf

Postareff, L., \& Lindblom-Ylanne, S. (2008). Variation in teachers' descriptions of teaching: Broadening the understanding of teching in higher education. Learning and Instruction, 18, 109-120. http://dx.doi.org/10.1016/j.learninstruc.2007.01.008

Rives-East, D., \& Lima, O. (2013). Designing Interdisciplinary Science/Humanities Courses: Challenges and Solutions. College Teaching, 61(3), 100-106. http://dx.doi.org/10.1080/87567555.20 12.752339

Russell, A. W., Wickson, F., \& Carew, A. L. (2008). Transdisciplinarity: context, contradictions, and capacity. Futures, 40, 460-472. http://dx.doi. org/10.1016/j.futures.2007.10.005

Scherpereel, C. M., \& Bowers, M. Y. (2006). Team Teaching in an Integrated Business Course. Development in Business Simulation and Experiential Learning, 33, 7-12.

Shibley Jr., I. A. (2006). Interdisciplinary team teaching. Negotiating pedagogical differences. College Teaching, 54(3), 271-274. http://dx.doi. org/10.3200/CTCH.54.3.271-274

Spelt, E. J. H., Biemans, H. J. A., Tobi, H., Luning, P. A., \& Mulder, M. (2009). Teaching and Learning in Interdisciplinary Higher Education: A Systematic Review. Educational Psychology Review, 21 (4), 365378. http://dx.doi.org/10.1007/s10648-009-9113-z

Šimanskienè, L., \& Seilius, A. (2009). Komandos: samprata, kūrimas, vadovavimas. Monografija. Klaipeda: Klaipèdos universiteto leidykla.

Weinberg, A., \& Harding, C. (2004). Interdisciplinary Teaching and Collaboration in Higher Education: A Concept Whose Time Has Come. Justice, Ethics, and Interdisciplinary Teaching and Practice, 14, 14-48.

Wenger, M. W., \& Hornyak, M. J. (1999). Team teaching for higher level learning: a framework of professional collaboration. Journal of Management Education, June, 311-327. http://dx.doi. org/10.1177/105256299902300308

West, M. A. (2011). Efektyvus komandinis darbas. Vilnius: Poligrafija ir informatika.

Wright, S., Byers, P., Dyball, M., Hazelton, J., \& Radich, R. (2011). Engaging Staff in Curriculum 
Change: Reflections from an Accounting Ethics Initiative. Asian Social Science, 7(11), 93-99. http://dx.doi.org/10.5539/ass.v7n11p93

Želvys, R. (2005). Vilniaus Pedagoginis universitetas XXI a. švietimo iššūkių kontekste. Pedagogika, 79, 17-22.
Želvys, R. (2007). Internacionalizacijos iššūkiai Lietuvos aukštajam mokslui. Acta Pedagogica Vilnensia, 17, 140-146.

Žydžiūnaitè, V. (2003). Komandinio darbo kompetenciju edukacine diagnostika ir ju vystymo, rengiant slaugytojus, pagrindimas. Kauno technologijos universitetas.

\section{Santrauka}

\section{Nijolè Putrienè. Tarpdalykinių studijų metu igyjamų kompetencijų ir darbo rinkos po- reikių sąsajos}

Šiuolaikinis verslo pasaulis yra ypatingai konkurencingas, keliantis aukštus reikalavimus jame dirbantiems specialistams. Darbuotojai turi būti jivaldę ivairius gebejjimus, turèti jivairių disciplinų žinių, mokèti dirbti komandose, prisiimti atsakomybę už savo ir savo komandos veiklą. Deja, darbdaviai neretai skundžiasi, kad jauni žmonès iš aukštojo mokslo instituciju išeina nepasirengę tokiai veiklai. Atsakydamos i naujus iššūkius, aukštojo mokslo institucijos turi keisti susiklosčiusias tradicijas. Ilgą laiką aukštojo mokslo institucijos visame pasaulyje kliovèsi disciplinomis, perteikdamos ir kurdamos naujas žinias. Toks žinių kūrimo modelis sprendè vienos konkrečios disciplinos klausimus ir nebuvo susijęs su socialinès aplinkos poreikiais (Light, Cox, \& Calkins, 2009). Tačiau darbo rinkai reikalingu kompetencijų kompleksiškumas kelia ir kèle poreiki sujungti disciplinas studiju programose. Šiu programu plètra, studentu poreikiu pokyčiai sudaré sąlygas ir kitam fenomenui - komandiniam déstymui aukštajame moksle - rastis. Tarpdalykinės studijos ir komandinis dèstymas radosi iš siekio patenkinti darbo rinkos poreikius, tačiau ar iš tikruju šie pokyčiai aukštajame moksle leidžia teigti, kad juos igyvendinus turètu kisti ir studijuojančiuju igyjamos kompetencijos? Kaip studentu mokymąsi veikia tarpdalykinès studijos ir komandinis dèstymas? Šie ir kiti klausimai tampa ypatingai svarbūs ieškant sąsajų tarp šiuolaikinès darbo rinkos ir studijas baigiančiu jaunuolių galimybių tapti sẻkmingais darbo rinkos dalyviais. Dèl šių priežasčių šiame straipsnyje keliamas klausimas, kokios darbo rinkai reikalingos kompetencijos yra ugdomos tarpdalykiniu studiju ir komandinio dèstymo jose metu. Straipsnyje naudojamas literatūros analizès metodas.

Straipsni sudaro trys dalys. Pirmoje straipsnio dalyje aptariamos tarpdalykiškumo ir tarpdalykiniu studiju programu sampratos. Tarpdalykiškumas (esantis tarp multidalykiškumo ir transdalykiškumo) yra aktyvaus mokslininku ir/ar destytoju bendradarbiavimo rezultate moksliniuose tyrimuose arba studijose kuriama lygiaverčiu disciplinu sąveika bei integracija, skirta tam, kad būtu sprendžiamos kompleksinès problemos ar analizuojami kompleksiniai fenomenai, igaunant labiau visumini šiu problemu ar fenomenu suvokimą. Tuo tarpu tarpdalykinę studiju programą galima apibrěžti kaip studiju programą, kurią sudaro dvieju ar daugiau disciplinu pagrindu parengti moduliai, kuriuos kuriant ir realizuojant svarbus dėstytoju (ir galimai studentu) iš skirtingų disciplinu aktyvus bendradarbiavimas, o mokymosi tikslas yra su(si)kurti analizuojamu fenomenu supratimą, paremtą nustatytu disciplinu žinių integracija ir sinteze.

Antroji straipsnio dalis yra skirta komandinio dèstymo apibréžties analizei. Nors mokslininkai (Buckeley, 1999; Day \& Hurrell, 2012; Gurgur \& Uzuner, 2011; Laughlin, Nelson, \& Donaldson, 2011; Wenger \& Hornyak, 1999) kiek skirtingai apibrě̌ia ši fenomeną, tačiau apibendrinus ju mintis, galima teigti, kad komandini desstymą rodo dvieju ar daugiau dèstytoju grupé, kuri dirba kartu planuodama ir vertindama tos pačios besimokančiuju grupès mokymąsi.

Trečiojoje straipsnio dalyje atskleidžiama tarpdalykiniu studiju ir komandinio dèstymo jose jtaka studentu igyjamoms kompetencijoms. Nustatyta, kad tarpdalykiniu studiju metu studentai išmoksta kurti naujas ar tobulinti turimas žinias, sujungdami ivairią informaciją, pažvelgti i situaciją iš skirtingu perspektyvu, mąstyti peržengiant nustatytas ribas, priimti sprendimus, remdamiesi dviprasmiška informacija. Be to, studiju metu lavinamas studentu gebejjimas komunikuoti su skirtingus požiūrius išreiškiančiais asmenimis bei priimti kitoki požiūri. Tuo tarpu komandinis dèstymas tarpdalykinèse studijose sudaro sąlygas aktyvesniam ir intensyvesniam studentu dalyvavimui užsièmimuose. Toks 
dèstymo būdas padeda studentams išmokti mokytis skirtingais būdais, sintezuoti žinias ir vertinti pateikiamą informaciją remiantis vertybinèmis nuostatomis, pagerina studentų informacijos supratimą bei jos išlaikymo lygi. Mokydamiesi iš dėstytojų komandų, studentai išmoksta vertinti skirtingus požiūrius, gebeti priimti ir teikti konstruktyvią kritiką, išreikšti savo nuomonę. Be to, tinkamai organizuojamas komandinis dėstymas gali supažindinti studentus su komandinio darbo niuansais. Taigi apibendrinant galima teigti, kad tarpdalykinėse studijose, kuriose vyksta komandinis dèstymas, studentai igyja gebejjimą i egzistuojančias problemas pažvelgti iš skirtingu perspektyvu, pripažinti skirtingus požiūrius, mąstyti išeidami iš „nustatytų rèmų“, išmoksta kurti naujas ir tobulinti turimas žinias, priimti ir teikti konstruktyvią kritiką, išreikšti savo nuomonę. Kadangi šios kompetencijos yra labai reikalingos dabartiniame darbo pasaulyje, galima teigti, kad tokiu būdu organizuojant studijas kuriamos prielaidos absolventų sèkmingai darbinei veiklai.

REIKŠMINIAI ŽODŽIAI: tarpdalykiškumas studijose, komandinis destymas, kompetencijos, darbo rinka.

\section{NIJOLÉ PUTRIENÉ}

About the

PhD student in Social Sciences (Educational Science)

Department of Educational Studies, Faculty of Social Sciences, Arts and Humanities,

Kaunas University of Technology

\section{Research interests}

Interdisciplinary studies, team-teaching in higher education, development of competencies of university teachers

\section{Address}

K. Donelaicio str. 73, Kaunas

E-mail: nijole.putriene@ktu.lt 